\title{
Arbovirosis and potential transmission blocking vaccines
}

\author{
Berlin Londono-Renteria*, Andrea Troupin and Tonya M. Colpitts
}

\begin{abstract}
Infectious diseases caused by arboviruses (viruses transmitted by arthropods) are undergoing unprecedented epidemic activity and geographic expansion. With the recent introduction of West Nile virus (1999), chikungunya virus (2013) and Zika virus (2015) to the Americas, stopping or even preventing the expansion of viruses into susceptible populations is an increasing concern. With a few exceptions, available vaccines protecting against arboviral infections are nonexistent and current disease prevention relies on vector control interventions. However, due to the emergence of and rapidly spreading insecticide resistance, different disease control methods are needed. A feasible method of reducing emerging tropical diseases is the implementation of vaccines that prevent or decrease viral infection in the vector. These vaccines are designated 'transmission blocking vaccines', or TBVs. Here, we summarize previous TBV work, discuss current research on arboviral TBVs and present several promising TBV candidates.
\end{abstract}

Keywords: Transmission blocking vaccines, Arbovirus, Arthropod, Vectors

\section{Background}

Infectious disease represents one the leading causes of mortality worldwide but it is especially problematic in tropical countries [1]. Among all infectious agents, viruses have been responsible for at least three major pandemics: smallpox, the "Spanish flu" (influenza virus) and the ongoing HIV/AIDS (human immunodeficiency virus) epidemic with more 30 million people affected globally $[2,3]$. Smallpox infection was one of the major causes of death worldwide, with a death toll between 300 and 500 million people. In the late 1700s, Dr Edward Jenner pioneered an immunization practice, which eventually led to the eradication of this disease in 1980 [4, 5]. The principle of the smallpox vaccine and other viral vaccines is to educate the body with a non-pathogenic but closely related microorganism. Consequently, this establishes immunological memory, strengthens the immune system and prevents future attacks from the invading virus $[6,7]$.

Improving living conditions plays an important role in decreasing the global incidence of viral diseases but the implementation of vaccines has also had a significant impact $[8,9]$. To date, several viral diseases have been

\footnotetext{
* Correspondence: blondono@uscmed.sc.edu

Department of Pathology, Microbiology and Immunology, University of

South Carolina, Columbia, South Carolina, USA
}

controlled with the help of vaccines and educational campaigns. In the early 2000s, measles and rubella were eliminated from the United States and had lower incidence rates worldwide due to aggressive vaccination efforts $[10,11]$. However, the re-emergence of mutant and drug resistant strains still poses a threat for the eradication of diseases like polio $[12,13]$, especially in areas with low vaccination coverage due to religious beliefs, lack of educational campaigns or general mistrust of health care workers providing the vaccines [13, 14]. Consequently, proper and timely education of the public is of pivotal importance in assuring and maintaining the efficacy of vaccination programs [15]. Vaccine efficacy and safety has improved considerably since Dr Jenner's rudimentary smallpox vaccine through the use of several new technologies. These developments include the production of live/attenuated, inactivated, toxoids and subunit/conjugate vaccines aiming to induce long lasting immunological memory in order to respond quickly to the invading pathogen [7].

The majority of available vaccines protect against communicable viral diseases; however, for the vast majority of 'arboviruses', the name given to viruses transmitted by arthropods (arthropod-borne viruses), there is no vaccine alternative yet. The exceptions of this rule include the 17D yellow fever virus (YFV) vaccine and the newly 
approved dengue virus (DENV) vaccine, Dengvaxia $[16,17]$. For decades, the main control method of arboviruses has relied on insecticide treatment of houses, reduction of breeding sites and limiting the vector-host contact (i.e., using a barrier protection like bed nets) [18-20]. New control strategies are needed due to increased insecticide resistance and the spreading of infectious arthropods to new areas [21, 22]. Unfortunately, insecticide resistance has spread to most countries endemic for vector-borne diseases [23]. Insect genetics and the continued/indiscriminate use of insecticides have largely contributed to the selection of resistant arthropods threatening the success of disease control programs [24, 25]. Fortunately, extensive research has shed some light onto the mechanism leading to resistance. For instance, insects can become insensitive to insecticide by metabolic resistance (metabolizing the insecticide faster than insecticide-sensitive strains), target modification (the insecticide-target molecule may change the structure/sequence) or behavioral modifications (indoor feeders changing to outdoor feeders) [26-28]. The presence of resistant mosquitoes in an area endemic for vector-borne diseases have a deleterious impact on public health control programs aimed to protect the population for exposure to infective arthropod bites [25]. Vector insecticide resistance also has a negative impact on economies as it pushes governments to use different and more expensive insecticides as well as requiring continuous re-treatment of areas [29, 30].

Climate variability has a direct impact on disease transmission since the life-cycle of the arthropod vector as well as the pathogen extrinsic incubation periods (EIPs), which depend on factors like temperature and humidity [31, 32], For instance, an increase in temperature has been associated with shorter extrinsic incubation periods and higher vector mortality [33-35]. Changes in vegetation and precipitation may induce an increase in mosquito densities in such a way that both factors are important predictors of mosquito abundance $[36,37]$ An example of the expansion of Aedes aegypti mosquitoes towards more temperate regions is depicted in Fig. 1 [38-40]. Tick life-cycle is also affected by climate fluctuations, helping several species to expand its territory to new higher altitudes due to warmer seasons [41]. Likewise, environmental and social factors also have a great impact on vector-borne diseases, associated with land use, water storage and seasonal work along with global travel all contribute to the rapid movement of human carriers and infected mosquitoes worldwide disseminating diseases [42-44].

Designing vaccines that prevent the pathogen from completing its life-cycle in the vector is one approach to halting transmission to humans [45]. Such vaccine alternatives have received the name of transmission blocking vaccines (TBVs). Different from traditional vaccines, TBVs aim to prevent infection in the transmitting vector rather than in the human host. They are also known as "altruistic vaccines", where the person receiving the vaccine may or may not be protected from infection but may prevent their neighbors from getting the disease [46, 47]. Interestingly enough, protecting one's neighbor could actually, in the end, prevent one's own new infection due to a phenomenon called "herd immunity" [48]. Since TBVs will have long-term effects they have to meet certain criteria to be widely accepted and implemented in the field. For example, besides having a high efficacy of infection prevention to the arthropod vector, care must be taken to avoid any cross-reactions or autoimmune disease in humans [49]. In addition, one of the most difficult challenges for TBVs is the maintenance of high antibody titers in vaccinated individuals due to the lack of natural

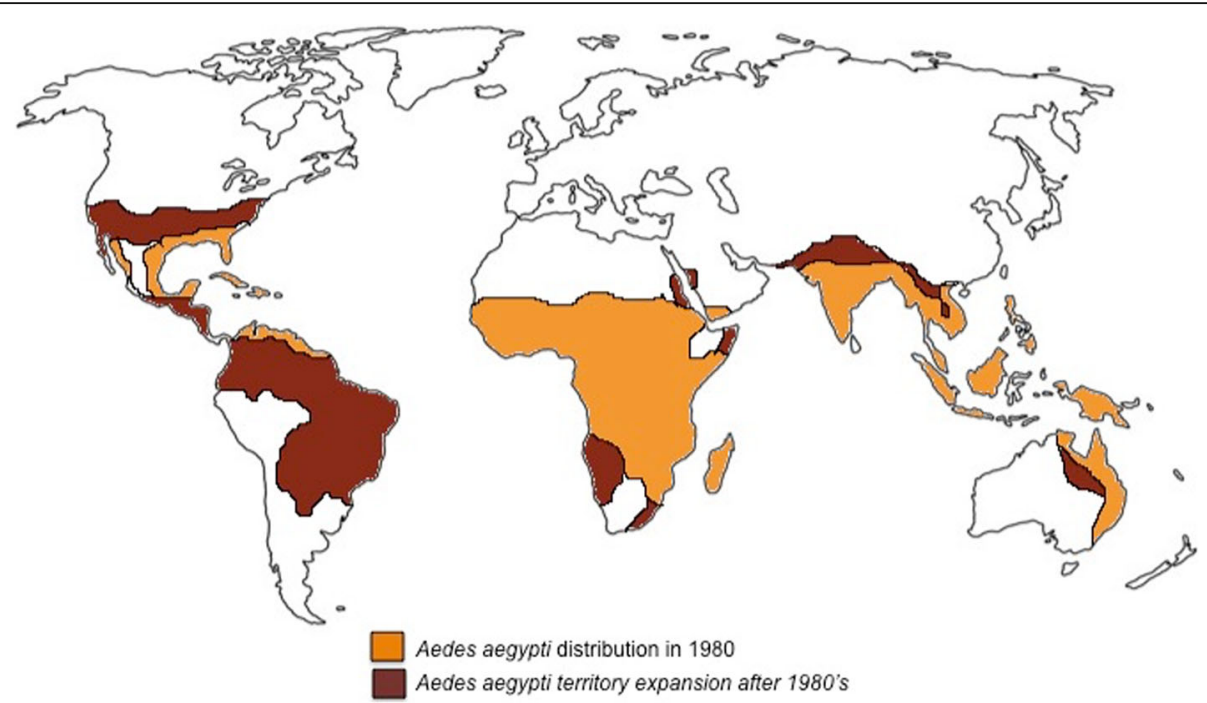

Fig. 1 Schematic representation of the Aedes aegypti mosquito geographical expansion from 1980 to 2016 
immunological boosting since majority of the proposed antigens are not normally found in the human but in the mosquito or tick vector [46, 47]. One way to solve this problem is through the use of adjuvants. Thus, significant effort has been put towards the design and implementation of new and safe adjuvants compatible with the vaccine formulations against mosquito, tick, or pathogen proteins $[50,51]$. Adjuvants like the nanoparticle-forming exoprotein from Pseudomonas aeruginosa A (EPA), the outermembrane protein complex (OMPC) of Neisseria meningitidis serogroup B and the IMX313, a chicken complement C4b-binding protein oligomerization domain, have shown to significantly increase antibody responses against the conjugated peptides $[52,53]$. A substantial review on other adjuvants and their mechanism of action can be found in Bergmann-Leitner et al. [54].

There is a growing concern regarding emerging and reemerging arboviruses in many parts of the world. In the last decade, the American continent has suffered the introduction of several mosquito-transmitted viruses. In the late 1990s, West Nile virus (WNV) was introduced to New York City. Recently, Central and South America have been the focus of the latest chikungunya virus (CHIKV) and Zika virus (ZIKV) epidemics [55, 56]. Interestingly, several TBVs targeting the transmission of malaria are currently in clinical trials $[57,58]$, suggesting that TBVs are a feasible method for limiting the spread of insect-borne diseases such as those caused by arboviruses. TBVs are an attractive tool to decrease arbovirus transmission, especially in the absence of specific antiviral treatments to prevent severity in high-risk populations, such as the elderly and pregnant women. The aim of this paper is to summarize the current TBV candidates for arboviruses and the most promising molecules that could be used in future TBV vaccine developments.

\section{Potential TBV impact on arboviral transmission}

There are approximately 3.5 billion people at risk of contracting diseases transmitted by arthropods. More specifically, one sixth of the total infectious diseases worldwide are spread by arthropod vectors [59]. There are even some cases where a single arthropod species is able to transmit more than one human pathogen in a given time. This is the case of Aedes aegypti, a prolific vector of many arboviruses including DENV, CHIKV, ZIKV and YFV [60-62]. Thus, a tool targeting transmission capacity in the vector rather than a single anti-microorganism human vaccine could be a practical control method for these diseases [60, 63].

Since the objective of the TBV vaccine is to halt new infection in transmission-competent insects, several approaches have been implemented to prevent infection in the vector (Fig. 2). To specify, most current TBV candidates focus on specific arthropod proteins while several others target pathogen antigens [64]. For instance, potential TBVs against DENV and WNV infections are designed using mosquito proteins required for viral infection of the mosquito vector $[65,66]$. Some of these proteins have shown to be essential for virion attachment to the target cells or for successful completion of the viral life-cycle [67]. Conversely, other TBV candidates consist of molecules required by the vector to obtain or digest nutrients $[68,69]$. Arthropod proteins carried by all members of the species may have an effect on vector feeding or physiological changes as well as impacting transmission capacity of all or several pathogens [70]. A summary of the most

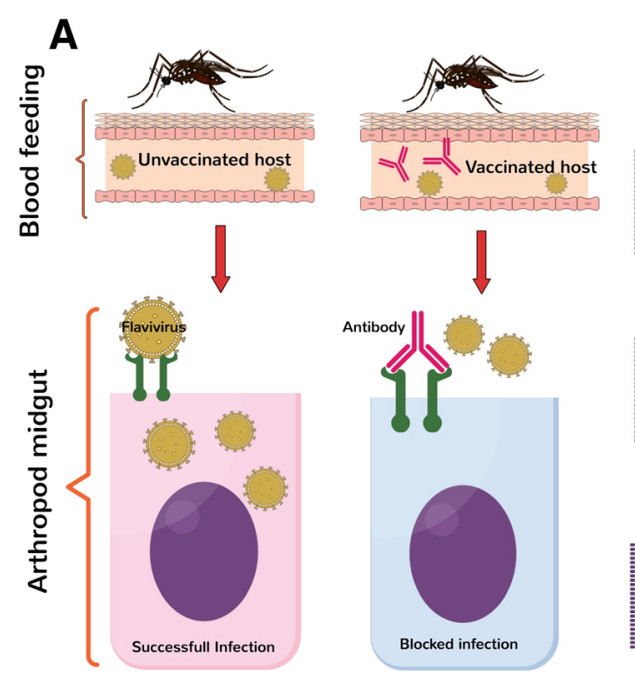

\section{B}

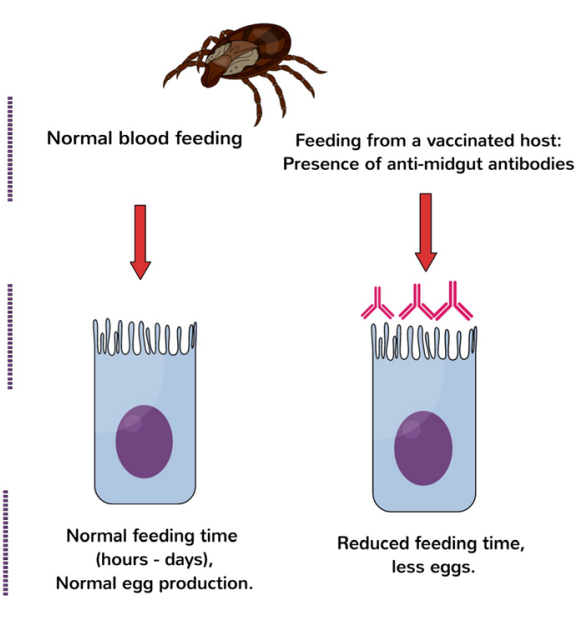

Fig. 2 Representation of the principal mechanisms of TBVs. a In the case of TBVs based on the vector proteins that interact with the pathogen, the vector will ingest antibodies against the target protein during blood feeding inhibiting the pathogen entrance to cells. $\mathbf{b}$ In second type of TBV, antibodies are directed against proteins required for blood digestion or egg production. Thus, when the arthropod feeds on a vaccinated host, those antibodies may kill the vectors or decrease their capacity to laid eggs 
promising arthropod antigens for TBVs can be found in Table 1.

\section{TBV to control arbovirosis transmitted by mosquitoes \\ West Nile virus}

WNV is a zoonotic arbovirus member of the Flavivirus genus and it is naturally maintained in an enzootic cycle between birds and mosquitoes [71]. Birds are the natural reservoir for WNV able to develop a transient high viremic titer allowing transmission of WNV to mosquitoes that preferentially feed on these birds. Migratory birds are of importance since they can carry the virus from one region to another [72]. Most bird infections with WNV results in non-fatal outcomes conferring a permanent immunity after infection [73]. However, several bird species, specially from the family Corvidae, do not usually survive WNV infection and are useful in tracking virus spread through dead-bird surveillance programs [74].

In addition, WNV virus infects horses and can be transmitted to humans in close contact with these animals [75]. Humans and horses are infected as incidental deadend hosts with insufficient viremia to perpetuate the transmission cycle, but this virus is able to cause small outbreaks in naïve populations [76]. Before 1990, this disease occurred sporadically as a minor risk for humans. The first cases of severe WNV were reported between 1994 and 1996 during the Algeria and Romania outbreaks where neurological complications were reported in several cases [77, 78]. WNV has now spread globally and although majority of infections are asymptomatic, elder populations as well as immune-compromised individuals are at high risk of severe disease [79]. The incidence of WNV has also increased worldwide in the last decade and now is the major cause of human encephalitis in USA $[80,81]$. One of the major epidemics in USA occurred in 2012 with more than 5000 human cases reported in 48 states that resulted in 286 deaths [82].

Several species are important vectors of WNV in USA, with Culex pipiens as one of the most important vectors, followed by Culex quinquifasciatus and Culex tarsalis [83]. However, at least 59 mosquito species have been identified as potential vectors and ten species have been confirmed as important vectors [84]. Consequently, continued surveillance as well as preventive methods are in need to control WNV infections in USA and worldwide.

Recent studies have demonstrated the role of C-type lectins in the establishment of Flavivirus, including WNV infection, in both mammals and the mosquito vector [85, 86]. For instance, Cheng et al. (2010) demonstrated that the knockdown of mosGCTL-1, or the feeding of mosquitoes with specific antibodies against the Aedes aegypti protein mosGCTL-1, significantly reduced WNV infection in both Aedes and Culex mosquitoes [65]. An upregulation of this protein is induced upon infection with WNV [65]. This study also showed that the Ae. aegypti C-type lectin (mosGCTL-1) interacts with WNV in a way that facilitates infection. MosGCTL-1 protein is recruited by mosPTP-1, an Ae. aegypti mosquito homolog of human $\mathrm{CD} 45$, which is a member of the of the protein tyrosine phosphatase (PTP) family. The interaction between mosGCTL-1 and mos-PTP-1 allows viral attachment to cells and enhances viral entry. Furthermore, both proteins are critical for WNV infection as demonstrated in experiments with Culex quinquifasciatus, the most competent vector for this virus [67]. Taking all this information together, mosGCTL-1 could be a potential target for a TBV against WNV.

\section{Dengue virus}

Dengue is currently one of the most important viral diseases of the tropics causing high morbidity and mortality in pediatric populations $[87,88]$. There are four distinct

Table 1 Main arthropod protein candidates for TBVs to control arboviruses

\begin{tabular}{|c|c|c|c|c|}
\hline Candidate molecule & Arthropod host & Function & Effect on disease & Available as vaccine \\
\hline mosGCTL-1 & Aedes aegypti & $\begin{array}{l}\text { Involved in WNV attachment by } \\
\text { interacting with PTP-1 [65] }\end{array}$ & Reduces WNV infection in mosquitoes & No \\
\hline mosGCTL-3 & Aedes aegypti & $\begin{array}{l}\text { Modulates virus entrance by interacting } \\
\text { with the DENV Envelope protein [67] }\end{array}$ & Reduce DENV infection in mosquitoes & No \\
\hline CRVP-379 & Aedes aegypti & $\begin{array}{l}\text { Interacts with the putative DENV receptor } \\
\text { prohibitin }[63,102]\end{array}$ & Blocks DENV infection in midgut & No \\
\hline CPB-1 & Aedes aegypti & $\begin{array}{l}\text { Midgut antigen. Interacts with the DENV } \\
\text { Envelope protein }[100,101]\end{array}$ & Reduces DENV infection in mosquito & No \\
\hline 64-TRP & $\begin{array}{l}\text { Rhipicepalus } \\
\text { appendiculatus }\end{array}$ & $\begin{array}{l}\text { Salivary antigen. Secures ticks mouth } \\
\text { parts during blood feeding }[136,137]\end{array}$ & $\begin{array}{l}\text { Reduces vector-host contact. Induces } \\
\text { death of blood feed ticks }\end{array}$ & No \\
\hline $\mathrm{Bm}-86$ & $\begin{array}{l}\text { Rhipicephalus } \\
\text { microplus }\end{array}$ & Midgut antigen $[131,134]$ & $\begin{array}{l}\text { Reduces blood uptake and vector-host } \\
\text { contact }\end{array}$ & Yes \\
\hline PpChit-1 & $\begin{array}{l}\text { Phlebotomus } \\
\text { papatasi }\end{array}$ & Aids maturation of peritrophic matrix [159] & Reduced sand fly life span and fecundity & No \\
\hline
\end{tabular}


DENV serotypes, DENV 1-4, all transmitted by Aedes spp. mosquitoes. While genetically closely related, each serotype differs in antigenicity, thus cross-protection is limited [89-91] and infection with any serotype induces lifelong immunity to only that specific serotype $[89,92]$. While the majority of DENV infections result in little or no disease, a small proportion progresses to severe forms: dengue with warning signs and severe dengue (WHO 2009) also known as dengue hemorrhagic fever (DHF) and dengue shock syndrome (DSS) [93]. The etiology of severe dengue is not completely understood; however, one of the most accepted theories suggests that dengue pathogenesis is related to antibody-enhanced infection (ADE) of DENV in Fc-receptor bearing target host cells [90]. Epidemiological studies suggest that antibodies to each of the four DENV are capable of enhancing further DENV infections. This phenomenon has been studied extensively in vitro and modeled in mice [94-97] and it is currently one of the challenges for the implementation of a protective vaccine against DENV infection.

An effective TBV for DENV should be able to block infection of all serotypes to prevent an increase in the severity of cases. Recent research has discovered several mosquito molecules with a critical role in DENV cell entry and replication $[98,99]$. As seen in WNV, several C-type lectins have been associated with Ae. aegypti and DENV infection. For instance, as mosGCTL-1 mediates the attachment of WNV on cell membranes, the Ae. aegypti, mosGCTL-3 is involved in DENV-2 infection. A recent study showed that mosGCTL-3 interacts directly with DENV envelope protein (Ep) and its gene expression is significantly upregulated upon DENV2 infection. After immunization, antibodies directed against mosGCTL-3 were able to disrupt mosquito infection with DENV-2 [67]. This indicates that GCTL-3 may be a suitable candidate for the development of a TBV.

Several suitable avenues in the search for TBV targets in mosquitoes have been explored. One approach, protein interaction screening, revealed that the Ae. aegypti carboxypeptidase $\mathrm{B} 1 \mathrm{CPB} 1$ ) is one of the predominant midgut proteins interacting with the DENV-2 Ep [100]. Previous studies suggested that CPB1 is upregulated after a blood meal and it is involved in the intra- and extracellular accumulation and secretion of infectious DENV-2 particles [101]. CPB1 was found throughout the cells but the Ep-CPB1 complex was only observed in the endoplasmic reticulum close to the nuclei. Tham et al. (2014) suggested that CPB1 is involved in regulating viral replication and the release of virion particles from midgut cells [100]. In the presence of CPB1, virus released from infected cells is predominantly immature, decreasing the chances for the virus to colonize salivary glands, and consequently reducing virus transmission to humans and other mammals [100].
Another protein candidate for a TBV against DENV infection is the putative cysteine rich venom protein 379 (CRVP379). CRVP379 expression is also upregulated by infection with DENV. Our group recently published that silencing CRVP379 significantly reduced DENV infection in Ae. aegypti mosquitoes. Additionally, we have found that CRVP379 is required for DENV infection and that it directly interacts with prohibitin, a putative receptor for DENV in Aedes spp. Blocking CRVP379 with specific antibodies recognizing the mosquito protein significantly reduced DENV infection in mosquitoes [66]. Additionally, CRVP379 has very low homology to any mammalian or human proteins. Since CRVP379 was found to be upregulated in WNV and YFV infections, we speculate that this protein is also required for infection of mosquitoes with these diseases; thus, antibodies against CRVP379 may also impact infection and subsequent transmission of other closely related flaviviruses [102]. If this hypothesis is correct, a TBV based on CRVP379 could have an enormous impact in places with concurrent transmission of these arboviruses, which is the case in most South and Central American countries. We are currently testing this hypothesis in our laboratory.

\section{Rift Valley fever virus}

Rift Valley fever virus (RVFV) is mainly maintained in the environment by transmission between animals (wild or domestic) and several mosquito species including Aedes, Culex and Anopheles [103, 104] although occasional transmission by other hematophagous insects has been reported [105, 106]. Most human cases of RVFV are mild; however, a small proportion progresses to the severe forms of the disease manifesting as meningoencephalitis or hemorrhagic fever [107, 108].

Although no TBV vaccine has been evaluated to control RVF infections, significant advances have been made in the biology of the mosquito vectors trying to block transmission of other diseases. For instance, the most promising Anopheles protein with potential of impacting RVFV transmission to date is the midgut protein alanyl aminopeptidase N (AnAPN1) [109]. This protein is present on the Anopheles gambiae midgut apical surface and it is believed to function as a receptor for Plasmodium ookinetes. Antibodies against AnAPN1 are able to inhibit $P$. falciparum parasite load [110]. Further investigation is needed to evaluate the effect of this protein in the development of RVFV in Anopheles and its further transmission to the vertebrate host.

\section{TBVs with the potential for targeting multiple diseases transmitted by other arthropods}

The blockage of arthropod proteins by the antibodies elicited against them through vaccines may have an impact not only on the lifespan of the arthropod vector 
but also on the transmission of most, if not all, microorganisms they carry $[111,112]$. These are vector-derived molecules involved in food digestion or feeding capacity [64]. Following, we present a list of candidates developed with the purpose of decreasing vector-host contact or halting midgut infection and salivary gland invasion.

\section{Ticks}

While mosquitoes represent the main vectors of human disease, ticks can also transmit several human pathogens and are the most important transmission vectors in veterinary medicine, serving as principal vectors of zoonotic diseases [113]. In blood feeding arthropods, midgut protein targets are preferred as this is the first organ in contact with blood factors and the newly invading pathogens $[114,115]$. In mosquitoes, blood can remain in the midgut for at least $24 \mathrm{~h}$ before all factors start degrading due to the action of digestive enzymes. On the contrary, tick blood digestion may take a few days [116]. Several tick species can feed and regurgitate during the blood meal uptake process increasing the chances of pathogen transmission, especially because undigested blood in the tick midgut can be stored for long periods allowing enough time for the virus to interact with epithelia [117-120]. Different from other blood-sucker arthropods, tick feeding process is characterized by digestion of blood at the intracellular vesicles of gut cells [121]. Since this phenomenon is special characteristic of ticks, there are current directed towards the characterization of digestive enzymes and feeding regulation that could lead to new alternative for TBV design $[122,123]$.

Tick infestation represented a significant nuisance for the cattle industry. Therefore, a great deal of effort was put into the design of non-chemical insecticides and a few vaccines are commercially available. For instance, Rhipicephalus spp. (formerly Boophilus spp.) is a major cattle pest in tropical and subtropical countries [124, 125]. Infestations with Rhipicephalus microplus (cattle tick), severely impacts the cattle by inhibiting weight gain and decreasing milk production $[125,126]$. Although there are reports that this species has been eradicated from most of USA, there are still cases of infestation leading to quarantine in bordering regions of Texas and California with Mexico [127]. Constant surveillance is implemented by the USDA Cattle Fever Tick Eradication Program to avoid the incursion of $R$. microplus into USA. The program consists of frequent patrolling/inspection of ranches in the Rio Grande area as well as acaricide prophylactic treatment and detention of smuggled livestock from Mexico [127, 128].

Rhipicephalus microplus is an important vector of Babesia bovis and Anaplasma marginale infections [129, 130]. In 1989, Willadsen et al. launched a new concept for the treatment of tick infestation. They described a tick gut antigen protein, $\mathrm{Bm}-86$, and found that antibodies raised against this protein were able to reduce blood uptake and egg production of Rhipicephalus ticks [131]. In the following years, Gavac ${ }^{\mathrm{Tx}}$ (Latin America) and TickGARD (Australia) vaccines based on the $\mathrm{Bm}-86$ protein were commercially available. Antibodies against Bm-86 bind to the surface of the tick's intestinal epithelial cells, which causes cell lysis. This leads to a reduction in the reproduction efficiency of Rhipicephalus ticks [132]. This vaccine also induces comparable antibody levels in different cattle breeds [133]. Interestingly, after the implementation of $\mathrm{Gavac}^{\mathrm{m}}$ in Cuba, several studies showed a significant reduction in the incidence of tick-borne cattle diseases and subsequently, mortality [134, 135]. Currently, TickGARD and Gavac ${ }^{\mathrm{Tm}}$ vaccine use is restricted to a small group of countries. However, effectiveness of these vaccines is restricted to Rhipicephalus ticks and efficacy may vary among tick strains [70, 135]. The development of new vaccines targeting other tick genera is needed.

Several anti-tick vaccine alternatives have been proposed. One of them is a vaccine based on a $15-\mathrm{kDa}$ tick saliva protein, 64TRP. The 64TRP acts like a 'cement' and helps the tick to secure the mouthparts on the host skin during feeding [136]. This protein was described in the tick species Rhipicephalus appendiculatus and it induces a strong humoral response [68]. In vivo studies in rodents have shown that antibodies against 64-TRP not only impair tick feeding but also cross-react with midgut antigens, resulting in the death of engorged ticks. Furthermore, antibodies against 64-TRP have shown to be effective against both adult and immature stages of several tick species [136, 137]. Labuda et al. [137] demonstrated that 64-TRP induces an immune response suitable for a TBV that has protective functions comparable to TickGARD against TBEV. Other targets have also been proposed to control tick infestation and prevent disease transmission. For a more complete catalogue of anti-tick vaccine alternatives please review the study by Merino et al. [111].

Another tick of medical importance in USA is the lone star tick, Amblyomma americanum, a common parasitic arthropod of cattle and dogs among other species $[138,139]$. This species is an important vector of Heartland and Bourbon virus, two emerging pathogens casing severe disease in humans in several regions within USA $[140,141]$. One study was found in the literature addressing the possibility of a TBV vaccine to prevent transmission of diseases by the lone star tick. In this study, de la Fuente et al. [142] identified several potential TBV candidates by RNAi-based screening of the A. americanum cDNA library. The most promising candidates were the subolesin and the interphase cytoplasm foci protein 45, 2G7. Cattle vaccinated with these proteins showed a significant antibody production and reduction 
in tick infestation [142]. Due to the alarming increase of cases by Heartland and Bourbon viruses, more investigation is needed into potential vaccine targets that would block their transmission to and from the vector.

Previous studies have shown that certain vertebrate hosts have the ability to develop anti-tick immunity after several exposures to a particular tick species [143]. Based on this principle, the European group, the ANTIDotE consortium, was created to develop TBVs against Ixodes ricinus to fight the diseases transmitted by this tick species. In contrast to the anti-Rhipicephalus vaccines directed against the arthropod gut, ANTIDotE vaccines are based on salivary antigens that have showed an impact on vector feeding behavior and pathogen transmission [144].

In USA, Ixodes scapularis is known as an important vector of Powassan virus (POWV) the causing agent of Powassan encephalitis endemic in North America and eastern Russia [145]. Mortality rate of Powassan encephalitis is below $11 \%$. However, infection with POWV may lead to severe neurological sequelae [145-147]. Incidence of Powassan encephalitis has increased in the last fifteen years but it is still a 'neglected' tick-borne disease in North America [148]. Most research on this tick species is directed to stop other bacterial or parasitic diseases transmitted by this species and yet there is little research on transmission blocking vaccine being designed to stop POWV transmission [149]. The ANTIDotE approach may also lead to POWV candidates, especially because, POWV is transmitted imbibed in tick saliva and transmission occurs in the first hours of blood feeding [150]. Since tick-borne diseases are in expansion, extensive research is needed to characterize the factors involved in tick-borne virus transmission to prevent new infections, control spread and avoid emergence into new areas.

\section{Sandflies and phleboviruses}

Several arboviruses are transmitted by sandflies in both Old and New World countries [151-154]. These viruses belong to the genera Phlebovirus, Vesiculovirus and Orbivirus $[155,156]$. Most research on sand fly-based TBVs is aimed to control leishmaniasis. However, it is possible that the use of candidate proteins involved in blood meal digestion, fecundity or life span of sandflies may also have an impact on other diseases transmitted by these arthropods [157, 158].

One example is chitinase 1 (PpChit-1), the midgut protein of Phlebotomus papatasi. This protein is involved in the maturation of the peritrophic matrix (PM), which is of pivotal importance in blood digestion [157]. Previous studies show that antibodies against this protein also cross-react with other midgut proteins from different Phlebotomus species [159]. Most importantly, treatment with antibodies against PpChit-1 negatively impacts the ability of sandflies to lay eggs. This is potentially caused by
PM permeability changes induced by the attaching antibodies. These changes affect nutrient absorption and egg development [159].

\section{Conclusions}

In this review, we provide examples of new advances in vaccine technology aimed to block or eliminate insectborne infectious diseases. Arboviruses are expanding not only geographically but they are also able to invade and be transmitted by a wide range of arthropods. At present, there are no specific treatments and very few vaccines that prevent most human arbovirus infections. Currently, prevention of arbovirus infection mainly relies on insecticide treatments, reduction of breeding sites and using barrier protection, such as bed nets or insecticide-impregnated clothing; however, these methods, although moderately effective, are not enough. Recently we have seen Heartland, CHIKV, and ZIKV virus outbreaks expand to the Americas at a rapid rate. In this regard, TBVs have the potential to decrease infection among certain populations while increasing herd immunity, which makes them an attractive tool to combat pathogen transmission and proliferation.

TBVs directed against specific arthropod molecules have the potential to impact most of the pathogens transmitted by a single vector. As with insecticides, there is always the possibility of resistance development against TBV vaccines, especially if genes with high selective pressure are targeted. To avoid possible selection, TBVs should be implemented along with other types of transmission control methods such as bed nets and insecticides to reduce vector population. In addition, combining pathogen and arthropod key target molecules in the same vaccine formulation may increase TBV efficacy and will confer protection against infection and transmission.

Access to vaccination and coverage strategies are very important factors in determining the effect of TBVs in countries endemic for specific diseases. Developing countries with economically challenged health care systems will greatly benefit from TBVs. Developing safe and affordable vaccine alternatives, along with community education, will improve the chances of reaching a broad distribution and effective vaccine coverage.

In summary, although significant advances have been made towards parasitic vector-borne diseases like malaria and leishmaniasis, further research is needed in TBV development for viral vector-borne diseases. TBVs represent a viable alternative to protect not only humans but also livestock.

\section{Abbreviations}

64TRP: Tick cement protein, truncated constructs of 64P; AnAPN1: Alanyl aminopeptidase N; CHIKV: Chikungunya; CPB1: Carboxypeptidase B1; CRVP379: Putative cysteine rich venom protein 379; CTL: C-type lectins; DENV: Dengue virus; POWV: Powassan virus; PpChit-1: Phlebotomus papatasi chitinase 1; PTP: Protein tyrosine phosphatase; RVFV: Rift Valley fever virus; 
TBEV: Tick-borne encephalitis; TBV: Transmission blocking vaccine; WNV: West Nile virus; YFV: Yellow fever virus; ZIKV: Zika virus

\section{Acknowledgements \\ Not Applicable.}

\section{Funding}

Not applicable.

\section{Availability of data and materials}

Not applicable.

\section{Authors' contributions}

BLR, AT and TMC conducted the bibliography search and manuscript writing All authors read and approved the final manuscript.

\section{Competing interests}

The authors declare that they have no competing interests.

\section{Consent for publication}

Not applicable.

\section{Ethics approval and consent to participate}

Not applicable.

Received: 7 June 2016 Accepted: 14 September 2016 Published online: 23 September 2016

\section{References}

1. Murray CJ, Lopez AD. Mortality by cause for eight regions of the world: global Burden of Disease Study. Lancet. 1997;349(9061):1269-76.

2. Cooper CL. Pandemic H1N12009 influenza and HIV: a review of natura history, management and vaccine immunogenicity. Curr Opin Infect Dis. 2012;25(1):26-35.

3. Johnson NP, Mueller J. Updating the accounts: global mortality of the 1918-1920 "Spanish" influenza pandemic. Bull Hist Med. 2002;76(1):105-15.

4. Bloch $\mathrm{H}$. Edward Jenner (1749-1823). The history and effects of smallpox, inoculation, and vaccination. Am J Dis Child. 1993;147(7):772-4

5. Riedel S. Edward Jenner and the history of smallpox and vaccination. Proc 2005;18(1):21-5

6. Lew-Tabor AE, Rodriguez Valle M. A review of reverse vaccinology approaches for the development of vaccines against ticks and tick borne diseases. Ticks Tick-Borne Dis. 2016;7(4):573-85.

7. Pulendran B, Ahmed R. Immunological mechanisms of vaccination. Nat Immunol. 2011;12(6):509-17.

8. La Montagne JR, Noble GR, Quinnan GV, Curlin GT, Blackwelder WC, Smith Jl, et al. Summary of clinical trials of inactivated influenza vaccine - 1978. Rev Infect Dis. 1983;5(4):723-36.

9. McBean AM, Thoms ML, Johnson RH, Gadless BR, MacDonald B, Nerhood L, et al. A comparison of the serologic responses to oral and injectable trivalent poliovirus vaccines. Rev Infect Dis. 1984;6 Suppl 2:S552-5.

10. Miller MA SJ, et al. Vaccine-preventable diseases. In: Jamison DT FR, Makgoba MW, editors. Disease and mortality in Sub-Saharan Africa. 2nd ed. Washington (DC): World Bank; 2006. Chapter 12.

11. Walsh B, Doherty E, O'Neill C. Since the start of the vaccines for children program, uptake has increased, and most disparities have decreased. Health Aff. 2016;35(2):356-64.

12. Delpeyroux F, Colbere-Garapin F, Razafindratsimandresy R, Sadeuh-Mba S, Joffret ML, Rousset D, Blondel B. Eradication of poliomyelitis and emergence of pathogenic vaccine-derived polioviruses: from Madagascar to Cameroon. Med Sci. 2013;29(11):1034-41

13. Toole MJ. So close: remaining challenges to eradicating polio. BMC Med. 2016;14:43.

14. Mbaeyi C, Saatcioglu A, Tangermann RH, Hadler S, Ehrhardt D. Progress toward poliomyelitis eradication-Afghanistan, January 2014 August 2015. MMWR Morb Mortal Wkly Rep. 2015;64(41):1166-70.

15. Whitty CJ. Political, social and technical risks in the last stages of disease eradication campaigns. Int Health. 2015;7(5):302-3.

16. Scott LJ. Tetravalent dengue vaccine: a review in the prevention of denque disease. Drugs. 2016;76(13):1301-12.
17. Wieten RW, Goorhuis A, Jonker EF, de Bree GJ, de Visser AW, van Genderen PJ, et al. 17D yellow fever vaccine elicits comparable long-term immune responses in healthy individuals and immune-compromised patients. J Infect. 2016;72(6):713-22.

18. Kean J, Rainey SM, McFarlane M, Donald CL, Schnettler E, Kohl A, Pondeville E. Fighting Arbovirus transmission: natural and engineered control of vector competence in Aedes Mosquitoes. Insects. 2015;6(1):236-78.

19. Baly A, Gonzalez K, Cabrera P, Popa JC, Toledo ME, Hernandez C, et al. Incremental cost of implementing residual insecticide treatment with delthametrine on top of intensive routine Aedes aegypti control. Trop Med Int Health. 2016:21(5):597-602.

20. Ocampo CB, Mina NJ, Carabali M, Alexander N, Osorio L. Reduction in dengue cases observed during mass control of Aedes (Stegomyia) in street catch basins in an endemic urban area in Colombia. Acta Trop. 2014;132:15-22.

21. Djouaka R, Riveron JM, Yessoufou A, Tchigossou G, Akoton R, Irving H, et al. Multiple insecticide resistance in an infected population of the malaria vector Anopheles funestus in Benin. Parasit Vectors. 2016;9:453.

22. Tonteri E, Kurkela S, Timonen S, Manni T, Vuorinen T, Kuusi M, Vapalahti O. Surveillance of endemic foci of tick-borne encephalitis in Finland 1995-2013: evidence of emergence of new foci. Euro surveill. 2015;20(37).

23. Benelli G. Research in mosquito control: current challenges for a brighter future. Parasitol Res. 2015;114(8):2801-5.

24. Maciel-de-Freitas R, Avendanho FC, Santos R, Sylvestre G, Araujo SC, Lima JB, et al. Undesirable consequences of insecticide resistance following Aedes aegypti control activities due to a dengue outbreak. PLoS One. 2014;9(3):e92424.

25. Nkya TE, Akhouayri I, Kisinza W, David JP. Impact of environment on mosquito response to pyrethroid insecticides: facts, evidences and prospects. Insect Biochem Mol Biol. 2013:43(4):407-16.

26. Liu N. Insecticide resistance in mosquitoes: impact, mechanisms, and research directions. Annu Rev Entomol. 2015;60:537-59.

27. Sokhna C, Ndiath $M O$, Rogier C. The changes in mosquito vector behaviour and the emerging resistance to insecticides will challenge the decline of malaria. Clin Microbiol Infect. 2013;19(10):902-7.

28. Kasai S, Komagata O, Itokawa K, Shono T, Ng LC, Kobayashi M, Tomita T. Mechanisms of pyrethroid resistance in the dengue mosquito vector, Aedes aegypti: target site insensitivity, penetration, and metabolism. PLoS Negl Trop Dis. 2014;8(6):e2948.

29. Pimentel D, Harvey C, Resosudarmo P, Sinclair K, Kurz D, McNair M, et al. Environmental and economic costs of soil erosion and conservation benefits. Science. 1995;267(5201):1117-23.

30. Mallet J. The evolution of insecticide resistance: have the insects won? Trends Ecol Evol. 1989;4(11):336-40.

31. Ogden $\mathrm{NH}$, Lindsay LR. Effects of climate and climate change on vectors and vector-borne diseases: ticks are different. Trends Parasitol. 2016:32(8):646-56

32. Medlock JM, Vaux AG. Impacts of the creation, expansion and management of English wetlands on mosquito presence and abundance - developing strategies for future disease mitigation. Parasit Vectors. 2015;8:142

33. Beck-Johnson LM, Nelson WA, Paaijmans KP, Read AF, Thomas MB, Bjornstad ON. The effect of temperature on Anopheles mosquito population dynamics and the potential for malaria transmission. PLoS One. 2013:8(11):e79276.

34. Watts DM, Burke DS, Harrison BA, Whitmire RE, Nisalak A. Effect of temperature on the vector efficiency of Aedes aegypti for dengue 2 virus. Am J Trop Med Hyg. 1987;36(1):143-52.

35. Rohani A, Wong YC, Zamre I, Lee HL, Zurainee MN. The effect of extrinsic incubation temperature on development of dengue serotype 2 and 4 viruses in Aedes aegypti (L.). Southeast Asian J Trop Med Public Health. 2009:40(5):942-50.

36. Gardner AM, Anderson TK, Hamer GL, Johnson DE, Varela KE, Walker ED Ruiz MO. Terrestrial vegetation and aquatic chemistry influence larval mosquito abundance in catch basins, Chicago, USA. Parasit Vectors. 2013:6:9.

37. Allan SA, Kline DL, Walker T. Environmental factors affecting efficacy of bifenthrin-treated vegetation for mosquito control. J Am Mosq Control Assoc. 2009;25(3):338-46.

38. Geographical distribution of arthropod-borne diseases and their principal vectors. [http://www.ciesin.org/docs/001-613/001-613.html]. Accessed 5 Sept 2016.

39. Estimated range of Aedes albopictus and Aedes aegypti in the United States, 2016* [http://www.cdc.gov/zika/vector/range.html]. Accessed 5 Sept 2016. 
40. Halstead SB, Suaya JA, Shepard DS. The burden of dengue infection. Lancet. 2007;369(9571):1410-1.

41. Leger E, Vourc'h G, Vial L, Chevillon C, McCoy KD. Changing distributions of ticks: causes and consequences. Exp Appl Acarol. 2013;59(1-2):219-44.

42. Deming R, Manrique-Saide P, Medina Barreiro A, Cardena EU, Che-Mendoza $A$, Jones $B$, et al. Spatial variation of insecticide resistance in the dengue vector Aedes aegypti presents unique vector control challenges. Parasit Vectors. 2016;9(1):67.

43. Takumi K, Scholte EJ, Braks M, Reusken C, Avenell D, Medlock JM. Introduction, scenarios for establishment and seasonal activity of Aedes albopictus in The Netherlands. Vector Borne Zoonotic Dis. 2009;9(2):191-6.

44. Whiten SR, Peterson RK. The influence of ambient temperature on the susceptibility of Aedes aegypti (Diptera: Culicidae) to the pyrethroid insecticide permethrin. J Med Entomol. 2016;53(1):139-43.

45. Matuschewski K, Mueller AK. Vaccines against malaria - an update. FEBS J. 2007;274(18):4680-7.

46. Neelakanta G, Sultana H. Transmission-blocking vaccines: focus on anti-vector vaccines against tick-borne diseases. Arch Immunol Ther Exp. 2015;63(3):169-79.

47. Coutinho-Abreu IV, Ramalho-Ortigao M. Transmission blocking vaccines to control insect-borne diseases: a review. Mem Inst Oswaldo Cruz. 2010;105(1):1-12.

48. Dinglasan RR, Jacobs-Lorena M. Flipping the paradigm on malaria transmission-blocking vaccines. Trends Parasitol. 2008;24(8):364-70.

49. Kaslow DC. Transmission-blocking vaccines: uses and current status of development. Int J Parasitol. 1997;27(2):183-9.

50. DeWeerdt S. Vaccines: the take-home lesson. Nature. 2012;484(7395):S24-5.

51. Pasquale AD, Preiss S, Silva FT, Garcon N. Vaccine adjuvants: from 1920 to 2015 and beyond. Vaccines. 2015;3(2):320-43.

52. Qian F, Wu Y, Muratova O, Zhou H, Dobrescu G, Duggan P, et al. Conjugating recombinant proteins to Pseudomonas aeruginosa ExoProtein A: a strategy for enhancing immunogenicity of malaria vaccine candidates. Vaccine. 2007;25(20):3923-33.

53. Li Y, Leneghan DB, Miura K, Nikolaeva D, Brian IJ, Dicks MD, et al. Enhancing immunogenicity and transmission-blocking activity of malaria vaccines by fusing Pfs25 to IMX313 multimerization technology. Sci Rep. 2016;6:18848.

54. Bergmann-Leitner ES, Leitner WW. Adjuvants in the driver's seat: how magnitude, type, fine specificity and longevity of immune responses are driven by distinct classes of immune potentiators. Vaccines. 2014;2(2):252-96

55. Fernandez-Salas I, Danis-Lozano R, Casas-Martinez M, Ulloa A, Bond JG, Marina CF, et al. Historical inability to control Aedes aegypti as a main contributor of fast dispersal of chikungunya outbreaks in Latin America. Antivir Res. 2015;124:30-42.

56. Petersen E, Wilson ME, Touch S, McCloskey B, Mwaba P, Bates M, et al. Rapid spread of Zika virus in the Americas - implications for public health preparedness for mass gatherings at the 2016 Brazil Olympic Games. Int J Infect Dis. 2016;44:11-5.

57. Shimp Jr RL, Rowe C, Reiter K, Chen B, Nguyen V, Aebig J, et al. Development of a Pfs25-EPA malaria transmission blocking vaccine as a chemically conjugated nanoparticle. Vaccine. 2013;31(28):2954-62.

58. Moreno A, Joyner C. Malaria vaccine clinical trials: what's on the horizon. Curr Opin Immunol. 2015;35:98-106.

59. Hill CA, Kafatos FC, Stansfield SK, Collins FH. Arthropod-borne diseases: vector control in the genomics era. Nat Rev Microbiol. 2005;3(3):262-8.

60. Dickson LB, Sanchez-Vargas I, Sylla M, Fleming K, Black WC. Vector competence in West African Aedes aegypti is flavivirus species and genotype dependent. PLoS Negl Trop Dis. 2014;8(10):e3153.

61. Black WC, Bennett KE, Gorrochotegui-Escalante N, Barillas-Mury CV, Fernandez-Salas I, de Lourdes MM, et al. Flavivirus susceptibility in Aedes aegypti. Arch Med Res. 2002;33(4):379-88.

62. Vazeille M, Mousson L, Martin E, Failloux AB. Orally co-infected Aedes albopictus from La Reunion Island, Indian Ocean, can deliver both dengue and chikungunya infectious viral particles in their saliva. PLoS Negl Trop Dis. 2010;4(6):e706

63. Bhatt S, Gething PW, Brady OJ, Messina JP, Farlow AW, Moyes CL, et al. The global distribution and burden of dengue. Nature. 2013;496(7446):504-7

64. Leitner WW, Wali T, Kincaid R, Costero-Saint Denis A. Arthropod vectors and disease transmission: translational aspects. PLoS Negl Trop Dis. 2015;9(11):e0004107.
65. Cheng G, Cox J, Wang P, Krishnan MN, Dai J, Qian F, et al. A C-type lectin collaborates with a CD45 phosphatase homolog to facilitate West Nile virus infection of mosquitoes. Cell. 2010;142(5):714-25.

66. Londono-Renteria B, Troupin A, Conway MJ, Vesely D, Ledizet M, Roundy $C M$, et al. Dengue virus infection of Aedes aegypti requires a putative cysteine rich venom protein. PLoS Pathog. 2015;11(10):e1005202.

67. Liu Y, Zhang F, Liu J, Xiao X, Zhang S, Qin C, et al. Transmission-blocking antibodies against mosquito C-type lectins for dengue prevention. PLoS Pathog. 2014;10(2):e1003931.

68. Havlikova S, Roller L, Koci J, Trimnell AR, Kazimirova M, Klempa B, Nuttall PA. Functional role of 64P, the candidate transmission-blocking vaccine antigen from the tick, Rhipicephalus appendiculatus. Int J Parasitol. 2009:39(13):1485-94

69. Nijhof AM, Taoufik A, de la Fuente J, Kocan KM, de Vries E, Jongejan F. Gene silencing of the tick protective antigens, Bm-86, Bm91 and subolesin, in the one-host tick Boophilus microplus by RNA interference. Int J Parasitol. 2007;37(6):653-62.

70. Odongo D, Kamau L, Skilton R, Mwaura S, Nitsch C, Musoke A, et al. Vaccination of cattle with TickGARD induces cross-reactive antibodies binding to conserved linear peptides of Bm-86 homologues in Boophilus decoloratus. Vaccine. 2007;25(7):1287-96.

71. van der Meulen KM, Pensaert MB, Nauwynck HJ. West Nile virus in the vertebrate world. Arch Virol. 2005;150(4):637-57.

72. Bergsman LD, Hyman JM, Manore CA. A mathematical model for the spread of West Nile virus in migratory and resident birds. Math Biosci Eng. 2016; 13(2):401-24.

73. Work TH, Hurlbut HS, Taylor RM. Indigenous wild birds of the Nile Delta as potential West Nile virus circulating reservoirs. Am J Trop Med Hyg. 1955;4(5):872-88.

74. Troupin A, Colpitts TM. Overview of West Nile virus transmission and epidemiology. Methods Mol Biol. 2016;1435:15-8.

75. Hernandez-Jover M, Roche S, Ward MP. The human and animal health impacts of introduction and spread of an exotic strain of West Nile virus in Australia. Prev Vet Med. 2013;109(3-4):186-204.

76. Day JF, Tabachnick WJ, Smartt CT: Factors That Influence the Transmission of West Nile Virus in Florida. J Med Entomol. 2015;53(5):743-54.

77. Kramer LD, Styer LM, Ebel GD. A global perspective on the epidemiology of West Nile virus. Annu Rev Entomol. 2008:53:61-81.

78. Londono-Renteria B, Colpitts TM. A brief review of west Nile virus biology. Methods Mol Biol. 2016;1435:1-13.

79. Winkelmann ER, Luo H, Wang T. West Nile virus infection in the central nervous system. F1000Research. 2016;5.

80. Murray KO, Mertens E, Despres P. West Nile virus and its emergence in the United States of America. Vet Res. 2010;41(6):67.

81. Hahn MB, Monaghan AJ, Hayden MH, Eisen RJ, Delorey MJ, Lindsey NP, et al. Meteorological conditions associated with increased incidence of West Nile virus disease in the United States, 2004-2012. Am J Trop Med Hyg. 2015;92(5):1013-22.

82. (CDC) CfDCaP: CDC Newsroom: CDC releases final West Nile virus national surveillance data for 2012. The Centers for Disease Control and Prevention (CDC). 2013. https://www.cdc.gov/media/releases/2013/a0513-west-nile.html.

83. Danforth ME, Reisen WK, Barker CM. The impact of cycling temperature on the transmission of West Nile virus. J Med Entomol. 2016;53(3):681-86.

84. Barrera R, MacKay A, Amador M, Vasquez J, Smith J, Diaz A, et al. Mosquito vectors of West Nile virus during an epizootic outbreak in Puerto Rico. J Med Entomol. 2010;47(6):1185-95.

85. Prommalikit O, Thisyakorn U. Association between mannose-binding lectin gene polymorphisms and susceptibility to dengue virus infection: a preliminary report. Southeast Asian J Trop Med Public Health. 2015;46 Suppl 1:29-34.

86. Perera-Lecoin M, Meertens $L$, Carnec $X$, Amara A. Flavivirus entry receptors: an update. Viruses. 2014;6(1):69-88.

87. Hagenlocher M, Delmelle E, Casas I, Kienberger S. Assessing socioeconomic vulnerability to dengue fever in Cali, Colombia: statistical vs expert-based modeling. Int J Health Geogr. 2013;12(1):36.

88. Gubler DJ. Dengue, urbanization and globalization: the unholy trinity of the 21(st) Century. Trop Med Health. 2011;39(4 Suppl):3-11.

89. Gujarati TP, Ambika G. Virus antibody dynamics in primary and secondary dengue infections. J Mathematical Biol. 2014;69(6)1773-1800.

90. Wahala WM, Silva AM. The human antibody response to dengue virus infection. Viruses. 2011;3(12):2374-95. 
91. de Alwis R, Beltramello M, Messer WB, Sukupolvi-Petty S, Wahala WM, Kraus A, et al. In-depth analysis of the antibody response of individuals exposed to primary dengue virus infection. PLoS Negl Trop Dis. 2011;5(6):e1188.

92. Guzman MG, Kouri G. Dengue: an update. Lancet Infect Dis. 2002;2(1):33-42.

93. Khetarpal N, Khanna I. Dengue fever: causes, complications, and vaccine strategies. J Immunol Res. 2016;2016:6803098.

94. Morens DM, Halstead SB, Marchette NJ. Profiles of antibody-dependent enhancement of dengue virus type 2 infection. Microb Pathog. 1987;3(4):231-7

95. Costa W, Fagundes CT, Valadao DF, Avila TV, Cisalpino D, Rocha RF, et al. Subversion of early innate antiviral responses during antibody-dependent enhancement of Dengue virus infection induces severe disease in immunocompetent mice. Med Microbiol Immunol. 2014;203(4):231-50.

96. Balsitis SJ, Williams KL, Lachica R, Flores D, Kyle JL, Mehlhop E, et al. Lethal antibody enhancement of dengue disease in mice is prevented by FC modification. PLoS Pathog. 2010;6(2):e1000790.

97. Halstead SB, Mahalingam S, Marovich MA, Ubol S, Mosser DM. Intrinsic antibody-dependent enhancement of microbial infection in macrophages: disease regulation by immune complexes. Lancet Infect Dis. 2010;10(10): $712-22$

98. Kuadkitkan A, Wikan N, Fongsaran C, Smith DR. Identification and characterization of prohibitin as a receptor protein mediating DENV-2 entry into insect cells. Virology. 2010;406(1):149-61.

99. Paingankar MS, Gokhale MD, Deobagkar DN. Dengue-2-virus-interacting polypeptides involved in mosquito cell infection. Arch Virol. 2010;155(9):1453-61.

100. Tham HW, Balasubramaniam VR, Tejo BA, Ahmad H, Hassan SS. CPB1 of Aedes aegypti interacts with DENV2 E protein and regulates intracellular viral accumulation and release from midgut cells. Viruses. 2014;6(12):5028-46.

101. Isoe J, Zamora J, Miesfeld RL. Molecular analysis of the Aedes aegypti carboxypeptidase gene family. Insect Biochem Mol Biol. 2009;39(1):68-73.

102. Colpitts TM, Cox J, Vanlandingham DL, Feitosa FM, Cheng G, Kurscheid S, et al. Alterations in the Aedes aegypti transcriptome during infection with West Nile, dengue and yellow fever viruses. PLoS Pathog. 2011;7(9):e1002189.

103. Ratovonjato J, Olive MM, Tantely LM, Andrianaivolambo L, Tata E, Razainirina $J$, et al. Detection, isolation, and genetic characterization of Rift Valley fever virus from Anopheles (Anopheles) coustani, Anopheles (Anopheles) squamosus, and Culex (Culex) antennatus of the Haute Matsiatra region, Madagascar. Vector Borne Zoonotic Dis. 2011;11(6):753-9.

104. Seufi AM, Galal FH. Role of Culex and Anopheles mosquito species as potential vectors of rift valley fever virus in Sudan outbreak, 2007. BMC Infect Dis. 2010;10:65.

105. Fontenille D, Traore-Lamizana M, Diallo M, Thonnon J, Digoutte JP, Zeller HG. New vectors of Rift Valley fever in West Africa. Emerg Infect Dis. 1998;4(2):289-93.

106. Ba Y, Sall AA, Diallo D, Mondo M, Girault L, Dia I, Diallo M. Re-emergence of Rift Valley fever virus in Barkedji (Senegal, West Africa) in 2002-2003: identification of new vectors and epidemiological implications. J Am Mosq Control Assoc. 2012;28(3):170-8.

107. Siam AL, Meegan JM, Gharbawi KF. Rift Valley fever ocular manifestations: observations during the 1977 epidemic in Egypt. Br J Ophthalmol. 1980;64(5):366-74.

108. Imam IZ, Darwish MA, Karamany RE. Epidemic of Rift Valley fever (RVF) in Egypt: virological diagnosis of RVF in man. J Egypt Public Health Assoc. 1978;53(3-4):205-8.

109. Parish LA, Colquhoun DR, Ubaida Mohien C, Lyashkov AE, Graham DR, Dinglasan RR. Ookinete-interacting proteins on the microvillar surface are partitioned into detergent resistant membranes of Anopheles gambiae midguts. J Proteome Res. 2011;10(11):5150-62.

110. Dinglasan RR, Kalume DE, Kanzok SM, Ghosh AK, Muratova O, Pandey A, Jacobs-Lorena M. Disruption of Plasmodium falciparum development by antibodies against a conserved mosquito midgut antigen. Proc Natl Acad Sci U S A. 2007;104(33):13461-6.

111. Merino O, Alberdi P, de la Lastra Perez JM, de la Fuente J. Tick vaccines and the control of tick-borne pathogens. Front Cell Infect Microbiol. 2013;3:30.

112. Kay BH, Kemp DH. Vaccines against arthropods. Am J Trop Med Hyg. 1994:50(6 Suppl):87-96.

113. Heyman P, Cochez C, Hofhuis A, van der Giessen J, Sprong H, Porter SR, et al. A clear and present danger: tick-borne diseases in Europe. Expert Rev Anti-Infect Ther. 2010;8(1):33-50.
114. Lal AA, Patterson PS, Sacci JB, Vaughan JA, Paul C, Collins WE, et al. Anti-mosquito midgut antibodies block development of Plasmodium falciparum and Plasmodium vivax in multiple species of Anopheles mosquitoes and reduce vector fecundity and survivorship. Proc Natl Acad Sci U S A. 2001;98(9):5228-33.

115. Cupp EW. Biology of ticks. Vet Clin North Am Small Anim Pract. 1991;21(1):1-26.

116. Franta Z, Frantova H, Konvickova J, Horn M, Sojka D, Mares M, Kopacek P. Dynamics of digestive proteolytic system during blood feeding of the hard tick Ixodes ricinus. Parasit Vectors. 2010;3:119.

117. Connat JL. Demonstration of regurgitation of gut content during blood meals of the tick Ornithodoros moubata. Possible role in the transmission of pathogenic agents. Parasitol Res. 1991;77(5):452-4.

118. Flicek BF. Rickettsial and other tick-borne infections. Crit Care Nurs Clin North Am. 2007;19(1):27-38.

119. Chambers TJ, Monath TP. Preface to volume 60 the flaviviruses: pathogenesis and immunity. Adv Virus Res. 2003;60:xiii-xiv.

120. Liu XY, Bonnet SI. Hard tick factors implicated in pathogen transmission. PLoS Negl Trop Dis. 2014;8(1):e2566.

121. Sojka D. Tick blood digestion. In: Mehlhorn H, editor. Encyclopedia of Parasitology. Berlin, Heidelberg: Springer Berlin Heidelberg; 2014. p. 1-4.

122. de la Fuente J, Kocan KM. Strategies for development of vaccines for control of ixodid tick species. Parasite Immunol. 2006;28(7):275-83.

123. Willadsen P. Anti-tick vaccines. Parasitology. 2004;129(Suppl):S367-87.

124. Puerta JM, Chaparro JJ, Lopez-Arias A, Arroyave SA, Villar D. Loss of in vitro efficacy of topical commercial acaricides on Rhipicephalus microplus (Ixodida: Ixodidae) from Antioquian farms, Colombia. J Med Entomol. 2015;52(6):1309-14.

125. Jonsson NN, Davis R, De Witt M. An estimate of the economic effects of cattle tick (Boophilus microplus) infestation on Queensland dairy farms. Aust Vet J. 2001;79(12):826-31.

126. Miller RS, Farnsworth ML, Malmberg JL. Diseases at the livestock-wildlife interface: status, challenges, and opportunities in the United States. Prev Vet Med. 2013;110(2):119-32.

127. Busch JD, Stone NE, Nottingham R, Araya-Anchetta A, Lewis J, Hochhalter C, et al. Widespread movement of invasive cattle fever ticks (Rhipicephalus microplus) in southern Texas leads to shared local infestations on cattle and deer. Parasit Vectors. 2014;7:188.

128. de Leon Perez AA, Teel PD, Auclair AN, Messenger MT, Guerrero FD, Schuster G, Miller RJ. Integrated strategy for sustainable cattle fever tick eradication in USA is required to mitigate the impact of global change. Front Physiol. 2012;3:195.

129. Aubry P, Geale DW. A review of bovine anaplasmosis. Transbound Emerg Dis. 2011;58(1):1-30

130. Barre N, Uilenberg G. Spread of parasites transported with their hosts: case study of two species of cattle tick. Rev Sci Tech. 2010;29(1):149-160-35-147.

131. Willadsen P, Riding GA, McKenna RV, Kemp DH, Tellam RL, Nielsen JN, et al. Immunologic control of a parasitic arthropod. Identification of a protective antigen from Boophilus microplus. J Immunol. 1989;143(4):1346-51.

132. Willadsen $P$, Jongejan F. Immunology of the tick-host interaction and the control of ticks and tick-borne diseases. Parasitol Today. 1999;15(7):258-62.

133. De La Fuente J, Rodriguez M, Garcia-Garcia JC. Immunological control of ticks through vaccination with Boophilus microplus gut antigens. Ann N Y Acad Sci. 2000:916:617-21.

134. Valle MR, Mendez L, Valdez M, Redondo M, Espinosa CM, Vargas M, et al. Integrated control of Boophilus microplus ticks in Cuba based on vaccination with the anti-tick vaccine Gavac. Exp Appl Acarol. 2004;34(3-4):375-82.

135. de la Fuente J, Kocan KM. Advances in the identification and characterization of protective antigens for recombinant vaccines against tick infestations. Expert Rev Vaccines. 2003;2(4):583-93.

136. Trimnell AR, Davies GM, Lissina O, Hails RS, Nuttall PA. A cross-reactive tick cement antigen is a candidate broad-spectrum tick vaccine. Vaccine. 2005:23(34):4329-41.

137. Labuda M, Trimnell AR, Lickova M, Kazimirova M, Davies GM, Lissina O, et al An antivector vaccine protects against a lethal vector-borne pathogen. PLoS Pathog. 2006;2(4):e27.

138. Childs JE, Paddock CD. The ascendancy of Amblyomma americanum as a vector of pathogens affecting humans in the United States. Annu Rev Entomol. 2003:48:307-37.

139. Koch HG. Suitability of birds and mammals as hosts for immature stages of the lone star tick, Amblyomma americanum (Acari: Ixodidae). J Med Entomol. 1981;18(2):93-8. 
140. Kosoy Ol, Lambert AJ, Hawkinson DJ, Pastula DM, Goldsmith CS, Hunt DC, Staples JE. Novel thogotovirus associated with febrile illness and death, United States, 2014. Emerg Infect Dis. 2015;21(5):760-4.

141. Savage HM, Godsey MS, Jr., Panella NA, Burkhalter KL, Ashley DC, Lash RR, et al. Surveillance for Heartland virus (Bunyaviridae: Phlebovirus) in Missouri during 2013: First Detection of virus in adults of Amblyomma americanum (Acari: Ixodidae). J Med Entomol. 2016.

142. de la Fuente J, Manzano-Roman R, Naranjo V, Kocan KM, Zivkovic Z, Blouin $\mathrm{EF}$, et al. Identification of protective antigens by RNA interference for control of the lone star tick, Amblyomma americanum. Vaccine. 2010;28(7):1786-95.

143. Schuijt TJ, Narasimhan S, Daffre S, DePonte K, Hovius JW, Van't Veer C, et al. Identification and characterization of /xodes scapularis antigens that elicit tick immunity using yeast surface display. PLoS One. 2011;6(1):e15926.

144. Sprong H, Trentelman J, Seemann I, Grubhoffer L, Rego RO, Hajdusek O, et al. ANTIDotE: anti-tick vaccines to prevent tick-borne diseases in Europe. Parasit Vectors. 2014;7:77.

145. Ebel GD. Update on Powassan virus: emergence of a North American tick-borne flavivirus. Annu Rev Entomol. 2010;55:95-110.

146. Gholam BI, Puksa S, Provias JP. Powassan encephalitis: a case report with neuropathology and literature review. Can Med Assoc J. 1999;161(11):1419-22.

147. Goldfield M, Austin SM, Black HC, Taylor BF, Altman R. A non-fatal human case of Powassan virus encephalitis. Am J Trop Med Hyg. 1973;22(1):78-81.

148. Hermance ME, Santos Rl, Kelly BC, Valbuena G, Thangamani S. Immune cell targets of infection at the tick-skin interface during Powassan virus transmission. PLoS One. 2016;11(5):e0155889.

149. Gomes-Solecki M. Blocking pathogen transmission at the source: reservoir targeted OspA-based vaccines against Borrelia burgdorferi. Front Cell Infect Microbiol. 2014;4:136.

150. Ebel GD, Kramer LD. Short report: duration of tick attachment required for transmission of powassan virus by deer ticks. Am J Trop Med Hyg. 2004;71(3):268-71.

151. Reeves WK, Kato CY, Gilchriest T. Pathogen screening and bionomics of Lutzomyia apache (Diptera: Psychodidae) in Wyoming, USA. J Am Mosa Control Assoc. 2008;24(3):444-7.

152. da Rosa Travassos AP, Tesh RB, da Rosa Travassos JF, Herve JP, Main Jr AJ. Carajas and Maraba viruses, two new vesiculoviruses isolated from phlebotomine sand flies in Brazil. Am J Trop Med Hyg. 1984;33(5):999-1006.

153. Amaro F, Ze-Ze L, Alves MJ, Borstler J, Clos J, Lorenzen S, et al. Co-circulation of a novel phlebovirus and Massilia virus in sandflies, Portugal. Virol J. 2015;12:174.

154. Alkan C, Bichaud L, de Lamballerie X, Alten B, Gould EA, Charrel RN. Sand fly-borne phleboviruses of Eurasia and Africa: epidemiology, genetic diversity, geographic range, control measures. Antivir Res. 2013;100(1):54-74.

155. Comer JA, Corn JL. Funnel trap for the capture of phlebotomine sand flies (Diptera: Psychodidae) from tree holes. J Med Entomol. 1991;28(2):289-92.

156. de la Fuente J, Rodriguez M, Redondo M, Montero C, Garcia-Garcia JC, Mendez $\mathrm{L}$, et al. Field studies and cost-effectiveness analysis of vaccination with Gavac against the cattle tick Boophilus microplus. Vaccine. 1998;16(4):366-73.

157. Coutinho-Abreu IV, Sharma NK, Robles-Murguia M, Ramalho-Ortigao M. Targeting the midqut secreted PpChit-1 reduces Leishmania major development in its natural vector, the sand fly Phlebotomus papatasi. PLoS Negl Trop Dis. 2010;4(11):e901.

158. Bates PA, Depaquit J, Galati EA, Kamhawi S, Maroli M, McDowell MA, et al. Recent advances in phlebotomine sand fly research related to leishmaniasis control. Parasit Vectors. 2015;8(1):131-9.

159. Robles-Murguia M, Bloedow N, Murray L, Ramalho-Ortigao M. Effect of mouse antisera targeting the Phlebotomus papatasi midgut chitinase PpChit-1 on sand fly physiology and fitness. Mem Inst Oswaldo Cruz. 2014:109(8):1064-9.

\section{Submit your next manuscript to BioMed Central and we will help you at every step:}

- We accept pre-submission inquiries

- Our selector tool helps you to find the most relevant journal

- We provide round the clock customer support

- Convenient online submission

- Thorough peer review

- Inclusion in PubMed and all major indexing services

- Maximum visibility for your research

Submit your manuscript at www.biomedcentral.com/submit
Biomed Central 